\title{
Factors Affecting Serum Trace Elements of Breeding Ewes in Central Saudi Arabia
}

\author{
D.R. Derar ${ }^{1,2}$, A. Ali ${ }^{1,2}$, T.I. Almundarij ${ }^{1}$, E.M. Abdel-Elmoniem ${ }^{1,3}$, T.M. Alhassun ${ }^{1}$
}

10.18805/IJAR.BF-1475

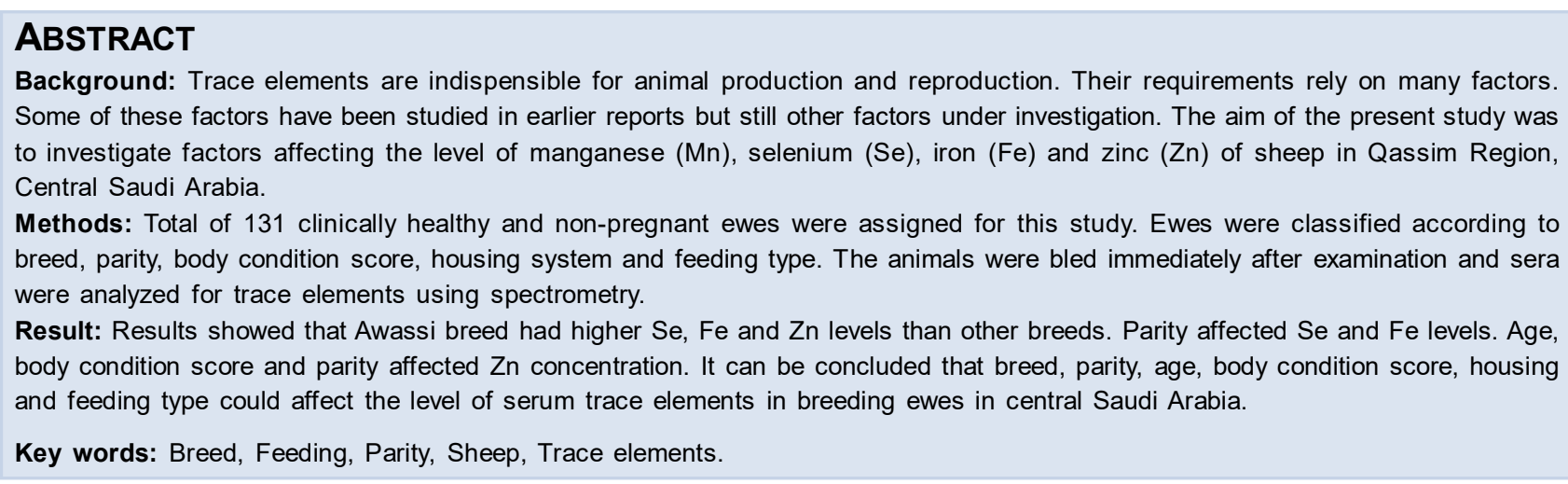

\section{INTRODUCTION}

The nutritional requirements of minerals and trace elements and their role in animal health and production are still an interesting area of research which acquired a wide range of debate among the nutritionist interested in human and animal welfare. Trace elements may function as activators of enzymes, as cofactors, or stabilizers of supplementary molecular construction (Nawito et al., 2015). Though, these elements are mostly required in small quantities but are quiet vital for optimum health and production (Ali et al, 2021).

Manganese $(\mathrm{Mn})$ is compulsory for growth, digestion and reproduction in ruminants. Retarded growth and poor ossification and high rate of bone fractures were noted in ewes raised on low manganese diets (Grace and Knowles, 2012; Uslu et al., 2017). Selenium (Se) is a cell antioxidant, which prevents harm of free oxygen and several peroxides formed from fatty acids (Gürdoğan et al., 2006; Ganie et al., 2014; Makhlouf et al., 2020). Body condition score, lambing rate has amplified with selenium supplementation (VázquezArmijo et al., 2011; Awawdeh et al., 2019). Iron (Fe) occurs in major quantities in blood and muscle as well as in many enzymes (Zhang et al., 2018). Zinc (Zn) is indispensable in the production of many of the sex hormones, comprising enzymes, steroid hormones and GnRH (Stefanidou et al., 2006; Nielsen, 2012).

There are several factors affecting the dynamic changes in the level of trace elements in the serum of sheep among them seasonality, sex, pregnancy, litter size and type of feeding (Grace and Knowles, 2012; Nawito et al., 2015; Makhlouf et al., 2020). Therefore, we hypothesize that before ration formulation and calculating the minimum requirement of these elements in feed these factors should be considered. The aim of this study was to investigate the effect of the breed, parity, age, body condition score, housing
${ }^{1}$ Department of Veterinary Medicine, College of Agriculture and Veterinary Medicine, Qassim University, Saudi Arabia.

${ }^{2}$ Department of Theriogenology, Faculty of Veterinary Medicine, Assiut University, Assiut-71526, Egypt.

${ }^{3}$ Department of Soil, College of Agriculture and Veterinary Medicine, Qassim University, Saudi Arabia.

Corresponding Author: D.R. Derar, Department of Veterinary Medicine, College of Agriculture and Veterinary Medicine, Qassim University, Saudi Arabia. Email: dr.mohammad@qu.edu.sa

How to cite this article: Derar, D.R., Ali, A., Almundarij, T.I., Elmoniem, E.M.A. and Alhassun, T.M. (2022). Factors Affecting Serum Trace Elements of Breeding Ewes in Central Saudi Arabia Indian Journal of Animal Research. DOI: 10.18805/IJAR.BF-1475.

Submitted: 06-12-2021 Accepted: 20-01-2022 Online: 17-02-2022

and feeding type on the serum level of trace elements of breeding ewes in Qassim region, central Saudi Arabia.

\section{MATERIALS AND METHODS}

This study was carried out at Qassim veterinary hospital (autumn/winter breeding seasons of the year 2020/2021). Total of 131 breeding ewes averaged 3.73 years age and 53.87 kgs weight in Qassim region, central Saudi Arabia, longitude $43-58^{\circ} \mathrm{E}$ and latitude $21-26^{\circ} \mathrm{N}$ were used in this study. Diets were formulated to meet or exceed the requirements of $50 \mathrm{~kg}$ maintenance ewe according to NRC for sheep (1985). The average daily feed intake was ranged from 1250 - to $1350 \mathrm{~g} / \mathrm{head} /$ day and drinking water ad libitum. Animals were categorized according to breed (Awassi, $n=49$ vs Harry, $n=36$ vs Hybrid, $n=32$ vs Najdi $n=14)$, Age, parity, body condition score (1-5 where 1 is skinny and 5 is overfed), feeding type [barseem, $n=66$ vs barseem+feed pellets (Table 1 shows the amount/percentage of nutritional ingredients in 
these pellets according to the manufacturer's prescription), $n=10$ vs barley, $n=22$ vs Barley + pellets, $n=33$ ], housing (open, the ewes were left unconfined in open areas, $n=34$ vs. closed, ewes were kept throughout the day and night in pens, $n=44$ vs. mixed, ewes were left free during the day and kept in pens at night, $\mathrm{n}=53$ ).

The animals were examined clinically for general health condition and thriftiness. For the gynecological examination, transrectal/Transabdominal ultrasonography using a $5 \mathrm{MHz}$ probe (Aloka Co., Ltd., Tokyo, Japan) was carried out. Only healthy, sound and non-pregnant ewes were used in the present study.

Blood was collected from the jugular vein of all studied ewes. The serum samples were separated by centrifugation for $10 \mathrm{~min}$ at $1200 \mathrm{xg}$ and were immediately frozen till the time of assay.

Serum was digested using $\mathrm{HClO} 4-\mathrm{HNO} 3$ mixture, according to the technique described previously (Antoniou et al., 1995). Concentrations of $\mathrm{Mn}, \mathrm{Se}, \mathrm{Fe}$ and $\mathrm{Zn}$ were

Table 1: Amount/percentages of nutrients in feed pellets used for feeding breeding ewes in Qassim region.

\begin{tabular}{lc}
\hline Ingredients & Amount or $\%$ \\
\hline Crude protein (\%) & $11.25 \%$ \\
Nitrogen (\%) & 1.8 \\
Phosphorus (\%) & 0.3 \\
Acid Detergent Fiber (\%) & 27 \\
Zinc (PPM) & 30 \\
Iron (PPM) & 110 \\
M.E. (MJ/Kg) & 11 \\
Potassium (\%) & 0.7 \\
Sodium (\%) & 0.3 \\
Calcium (\%) & 0.6 \\
Manganese (ppm) & 40 \\
\hline
\end{tabular}

determined by flame emission atomic absorption (Thermo Scientific, Mosel:iCAP 7400 Duo, USA) based on the previously described technique (Moffat et al., 1986).

The data were presented in means \pm SE and statistical analysis was carried out using the SPSS program, version 25 (SPSS Inc., Chicago, IL, USA, 2017). Data were analyzed by the GLM procedures for the effect of different factors on the serum concentration of trace elements in ewes. Relationships were estimated by the correlation coefficient. Significance was set at $\mathrm{P}<0.05$.

\section{RESULTS AND DISCUSSION}

Breed had a significant effect on Se $(P=0.001)$, Fe $(P=0.009)$ and $\mathrm{Zn}(P=0.045)$. Awassi breed had higher levels of Se, $\mathrm{Fe}$ and $\mathrm{Zn}$ than other breeds (Table 2). Parity had a significant effect on serum Se $(P=0.03)$, Fe $(P=0.01)$ and Zn ( $P=0.02)$ (Table 3). Serum Mn ( $P=0.003)$, Se $(P=0.001)$ and $\mathrm{Fe}(\mathrm{P}=0.001)$ levels were affected by the type of feeding. Ewes fed on barseem had lower serum Mn (Table 4). Positive correlation between parity and $\mathrm{Se}(\mathrm{P}=0.015)$ and parity and Fe $(P=0.02)$ were found.

Breed, parity and type of feeding had a significant effect on Serum Se in the present study. The effect of genetic predisposition on the level of trace elements has been discussed and a strong relationship between the human race or animal species with the level of trace elements was found. Selenium is reportedly associated with the formation of histones and DNA (Hosnedlova et al., 2017). The genotype of an animal affects its energy and protein requirements (Sahlu et al., 2004), Awassi ewes had a distinguished profile of serum trace elements compared to other breeds in the present study. Awassi breed have been found to be more adaptable to arid conditions than other breeds in Saudi Arabia (Abdelqader et al., 2012; Ali et al., 2020).

Table 2: The effect of breed on the level of serum manganese $(\mathrm{Mn})$, selenium $(\mathrm{Se})$, iron $(\mathrm{Fe})$ and zinc $(\mathrm{Zn})$ of ewes.

\begin{tabular}{lccccc}
\hline Breed & $\mathrm{n}$ & $\mathrm{Mn}(\mathrm{mg} / \mathrm{L})$ & Se $(\mathrm{mg} / \mathrm{L})$ & $\mathrm{Fe}(\mathrm{mg} / \mathrm{L})$ & $\mathrm{Zn}(\mathrm{mg} / \mathrm{L})$ \\
\hline Harry & 36 & $2.71 \pm 0.23^{\mathrm{a}}$ & $0.41 \pm 0.05^{\mathrm{a}}$ & $6.64 \pm 0.71^{\mathrm{a}}$ & $3.88 \pm 0.49^{\mathrm{a}}$ \\
hybrid & 32 & $3.53 \pm 0.58^{\mathrm{a}}$ & $0.80 \pm 0.08^{\mathrm{a}}$ & $8.26 \pm 1.94^{\mathrm{a}}$ & $9.92 \pm 3.19^{\mathrm{b}}$ \\
Najdy & 14 & $3.01 \pm 0.57^{\mathrm{a}}$ & $0.51 \pm 0.04^{\mathrm{a}}$ & $8.18 \pm 0.96^{\mathrm{a}}$ & $5.10 \pm 0.63^{\mathrm{a}}$ \\
Awassi & 49 & $5.21 \pm 3.59^{\mathrm{a}}$ & $4.24 \pm 3.65^{\mathrm{b}}$ & $12.03 \pm 1.41^{\mathrm{b}}$ & $10.66 \pm 3.56^{\mathrm{b}}$ \\
\hline
\end{tabular}

Values are presented as means \pm standard error. Values with the same superscript letter in the same column are not significantly different. Statistical significance was set at $P<0.05$.

Table 3: The effect of parity on the level of serum manganese (Mn), selenium (Se), iron (Fe) and zinc ( $\mathrm{Zn})$ of ewes.

\begin{tabular}{llllll}
\hline Parity & $\mathrm{n}$ & $\mathrm{Mn}(\mathrm{mg} / \mathrm{L})$ & $\mathrm{Se}(\mathrm{mg} / \mathrm{L})$ & $\mathrm{Fe}(\mathrm{mg} / \mathrm{L})$ & $\mathrm{Zn}(\mathrm{mg} / \mathrm{L})$ \\
\hline 0 & 23 & $2.01 \pm 0.54^{\mathrm{a}}$ & $0.25 \pm 0.01^{\mathrm{a}}$ & $5.93 \pm 0.12^{\mathrm{a}}$ & $2.29 \pm 0.08^{\mathrm{a}}$ \\
1 & 29 & $3.60 \pm 0.31^{\mathrm{a}}$ & $0.37 \pm 0.03^{\mathrm{a}}$ & $9.53 \pm 0.28^{\mathrm{a}}$ & $3.84 \pm 0.04^{\mathrm{a}}$ \\
2 & 31 & $3.05 \pm 0.41^{\mathrm{a}}$ & $0.50 \pm 0.02^{\mathrm{a}}$ & $7.61 \pm 0.93^{\mathrm{a}}$ & $7.19 \pm 1.54^{\mathrm{a}}$ \\
3 & 21 & $2.58 \pm 0.23^{\mathrm{a}}$ & $0.58 \pm 0.07^{\mathrm{a}}$ & $8.80 \pm 0.87^{\mathrm{a}}$ & $5.61 \pm 0.87^{\mathrm{a}}$ \\
4 & 16 & $3.99 \pm 0.35^{\mathrm{a}}$ & $1.87 \pm 0.09^{\mathrm{b}}$ & $7.75 \pm 0.76^{\mathrm{a}}$ & $6.26 \pm 1.37^{\mathrm{a}}$ \\
$>5$ & 11 & $4.32 \pm 1.05^{\mathrm{a}}$ & $0.72 \pm 0.05^{\mathrm{a}}$ & $14.41 \pm 1.23^{\mathrm{b}}$ & $15.79 \pm 3.28^{\mathrm{b}}$ \\
\hline
\end{tabular}

Values are presented as means \pm standard error. Values with the same superscript letter in the same column are not significantly different. Statistical significance was set at $\mathrm{P}<0.05$. 
Older ewes had a higher $\mathrm{Zn}$ level than younger ones (Table 7). Age $(P=0.001)$, BCS $(P=0.008)$ and Parity $(P=0.03)$ had positive effects on $\mathrm{Zn}$. Earlier reports indicated that the level of trace elements is significantly influenced by parity of sheep and goats (Gürdogan et al., 2006). Accordingly, levels of serum Se, Fe and $\mathrm{Zn}$ were higher in older and multiparous ewes. Although there is a concept that maternal stores of minerals deplete with age and repeated pregnancies, the fact that most minerals increase in older females is undeniable (Singh et al., 2010). The higher demand of nutrition during pregnancy and associated increase in metabolic processes including mobilization of the trace elements from the maternal tissue to the circulation during pregnancy is probably sustainable after birth (Ugwuja et al., 2015; Kumar et al., 2011). The affordable food quantity and quality improve during pregnancy as a part of the regular routine management which may explain the increasingly high levels of trace elements with increased parity (Kumar et al., 2017).

Although forages are rich in trace elements, their formulation and contents are affected by the type of soil where they grow. Concentrations of these elements in soil and their availability in plants affect their richness in the crop and the amount detected in green substance and seeds as well. Hence, many concerns about the animal's productive and reproductive performance arise from the type of soil where cultivation takes place (Hill and Shannon, 2019). Barseem cultivated in semiarid, arid and reclaimed soils, as the case in Qassim region, characterized by lower $\mathrm{Mn}, \mathrm{Cu}$ and Fe contents (Nawito et al., 2015). It has been illustrated that the metal build-up in the aforementioned soils is not high enough to cause considerable accumulation of these trace elements in barseem roots, probably due to high oxides in soils, which play a great role in reducing their availability (Grace and Knowles, 2012; Abuzaid et al., 2021; Al-Turki et al., 2020). It is generally accepted that most of the Arabian Peninsula is suffering from trace elements imbalance (Ali et al., 2021).

Animals housed in closed pens had lower serum $\mathrm{Zn}$ $(P=0.03)$ values than those managed in open and mixed management system (Table 5). Housing and BCS of the studied ewes affected significantly serum $\mathrm{Zn}$ level. Ewes housed in confined pens showed lower serum $\mathrm{Zn}$ levels. It is accepted that feed availability and quality provided to the animals depends solely on the individual awareness of the breeder and his knowledge (Dhok and Rekhate, 2008; Kumar et al., 2017). The vast majority of managers are illiterate or averagely educated (Ali et al., 2020). It is not surprising that most of the animals in closed pens receive inadequate amounts of trace elements despite the fact that they receive the adequate amount of feed for maintenance. It was interesting enough to find that more than $80 \%$ of ewes managed in closed pens fed only Barseem.

Serum $\mathrm{Zn}$ increased significantly $(P=0.008)$ in ewes with body condition score 4 (Table 6 ). There was a positive correlation between BCS and $\mathrm{Zn}$ in this study. In modern

Table 4: The effect of feeding type on the level of serum manganese (Mn), Selenium (Se), iron (Fe) and Zinc ( $\mathrm{Zn})$ of ewes.

\begin{tabular}{lccccc}
\hline Breed & $\mathrm{n}$ & $\mathrm{Mn}(\mathrm{mg} / \mathrm{L})$ & $\mathrm{Se}(\mathrm{mg} / \mathrm{L})$ & $\mathrm{Fe}(\mathrm{mg} / \mathrm{L})$ & $\mathrm{Zn}(\mathrm{mg} / \mathrm{L})$ \\
\hline Barseem & 66 & $2.22 \pm 0.25^{\mathrm{a}}$ & $0.52 \pm 0.04^{\mathrm{a}}$ & $9.21 \pm 0.63^{\mathrm{a}}$ & $4.75 \pm 0.35^{\mathrm{a}}$ \\
Pellets + Barseem & 10 & $5.2 \pm 1.31^{\mathrm{b}}$ & $2.44 \pm 1.43^{\mathrm{b}}$ & $10.33 \pm 2.16^{\mathrm{a}}$ & $8.78 \pm 1.64^{\mathrm{a}}$ \\
Barley & 22 & $4.46 \pm 2.61^{\mathrm{b}}$ & $0.8 \pm 0.01^{\mathrm{a}}$ & $29.05 \pm 7.54^{\mathrm{b}}$ & $8.21 \pm 2.35^{\mathrm{a}}$ \\
pellets + barley & 33 & $3.71 \pm 0.45^{\mathrm{b}}$ & $0.49 \pm 0.06^{\mathrm{a}}$ & $6.76 \pm 1.25^{\mathrm{a}}$ & $7.06 \pm 2.26^{\mathrm{a}}$ \\
\hline
\end{tabular}

Values are presented as means \pm standard error. Values with the same superscript letter in the same column are not significantly different. Statistical significance was set at $\mathrm{P}<0.05$.

Table 5: The effect of housing system on the level of serum manganese (Mn), selenium (Se), iron (Fe) and zinc ( $\mathrm{Zn})$ of ewes.

\begin{tabular}{|c|c|c|c|c|c|}
\hline Housing system & $\mathrm{n}$ & $\mathrm{Mn}(\mathrm{mg} / \mathrm{L})$ & $\mathrm{Se}(\mathrm{mg} / \mathrm{L})$ & $\mathrm{Fe}(\mathrm{mg} / \mathrm{L})$ & $\mathrm{Zn}(\mathrm{mg} / \mathrm{L})$ \\
\hline Closed & 44 & $2.13 \pm 0.18^{a}$ & $0.41 \pm 0.04^{a}$ & $7.60 \pm 1.18^{a}$ & $4.08 \pm 0.52^{a}$ \\
\hline open & 14 & $3.74 \pm 0.76^{a}$ & $0.67 \pm 0.06^{a}$ & $7.54 \pm 1.20^{a}$ & $9.57 \pm 1.13^{b}$ \\
\hline Mixed & 73 & $3.54 \pm 0.41^{\mathrm{a}}$ & $0.80 \pm 0.21^{a}$ & $9.41 \pm 0.98^{a}$ & $6.55 \pm 1.63^{b}$ \\
\hline
\end{tabular}

Values are presented as means \pm standard error. Values with the same superscript letter in the same column are not significantly different. Statistical significance was set at $\mathrm{P}<0.05$.

Table 6: The effect of body condition score (BCS) on the level of serum manganese (Mn), selenium (Se), iron (Fe) and zinc (Zn) of ewes.

\begin{tabular}{|c|c|c|c|c|c|}
\hline$\overline{\mathrm{BCS}}$ & $\mathrm{n}$ & $\mathrm{Mn}(\mathrm{mg} / \mathrm{L})$ & $\mathrm{Se}(\mathrm{mg} / \mathrm{L})$ & $\mathrm{Fe}(\mathrm{mg} / \mathrm{L})$ & $\mathrm{Zn}(\mathrm{mg} / \mathrm{L})$ \\
\hline 2.5 & 18 & $2.05 \pm 0.61^{a}$ & $0.83 \pm 0.09^{a}$ & $8.37 \pm 1.61^{a}$ & $10.28 \pm 3.61^{a}$ \\
\hline 3 & 71 & $3.00 \pm 0.42^{a}$ & $0.66 \pm 0.05^{a}$ & $8.51 \pm 1.45^{a}$ & $5.45 \pm 1.73^{a}$ \\
\hline 3.5 & 27 & $2.59 \pm 0.81^{a}$ & $0.49 \pm 0.07^{a}$ & $8.90 \pm 1.94^{a}$ & $5.48 \pm 1.54^{a}$ \\
\hline 4 & 15 & $4.64 \pm 0.93^{a}$ & $0.59 \pm 0.04^{a}$ & $10.49 \pm 2.21^{a}$ & $19.23 \pm 3.78^{b}$ \\
\hline
\end{tabular}

Values are presented as means \pm standard error. Values with the same superscript letter in the same column are not significantly different. Statistical significance was set at $\mathrm{P}<0.05$. 
Factors Affecting Serum Trace Elements of Breeding Ewes in Central Saudi Arabia

Table 7: The effect of age on the level of serum manganese $(\mathrm{Mn})$, selenium $(\mathrm{Se})$, iron $(\mathrm{Fe})$ and zinc $(\mathrm{Zn})$ of ewes.

\begin{tabular}{llllll}
\hline Age (year) & $\mathrm{n}$ & $\mathrm{Mn}(\mathrm{mg} / \mathrm{L})$ & $\mathrm{Se}(\mathrm{mg} / \mathrm{L})$ & $\mathrm{Fe}(\mathrm{mg} / \mathrm{L})$ & $\mathrm{Zn}(\mathrm{mg} / \mathrm{L})$ \\
\hline $1->2$ & 13 & $1.64 \pm 0.54^{\mathrm{a}}$ & $0.14 \pm 0.04^{\mathrm{a}}$ & $4.15 \pm 0.63^{\mathrm{a}}$ & $3.28 \pm 2.61^{\mathrm{c}}$ \\
$2->3$ & 15 & $3.11 \pm 0.61^{\mathrm{a}}$ & $0.59 \pm 0.06^{\mathrm{a}}$ & $10.53 \pm 1.94^{\mathrm{a}}$ & $3.49 \pm 1.45^{\mathrm{a}}$ \\
$3->4$ & 32 & $3.19 \pm 0.81^{\mathrm{a}}$ & $0.81 \pm 0.07^{\mathrm{a}}$ & $10.31 \pm 0.93^{\mathrm{a}}$ & $5.90 \pm 0.18^{\mathrm{a}}$ \\
$4->5$ & 39 & $2.30 \pm 0.63^{\mathrm{a}}$ & $0.52 \pm 0.01^{\mathrm{a}}$ & $10.32 \pm 1.45^{\mathrm{a}}$ & $6.40 \pm 0.78^{\mathrm{a}}$ \\
$5->6$ & 22 & $3.59 \pm 0.35^{\mathrm{a}}$ & $0.64 \pm 0.09^{\mathrm{a}}$ & $8.52 \pm 0.12^{\mathrm{a}}$ & $6.79 \pm 0.35^{\mathrm{a}}$ \\
$\leq 6$ & 10 & $4.46 \pm 0.41^{\mathrm{a}}$ & $0.63 \pm 0.05^{\mathrm{a}}$ & $9.61 \pm 1.73^{\mathrm{a}}$ & $19.12 \pm 1.31^{\mathrm{b}}$ \\
\hline
\end{tabular}

Values are presented as means \pm standard error. Values with the same superscript letter in the same column are not significantly different. Statistical significance was set at $\mathrm{P}<0.05$.

technology of sheep production, the determination of nutritional requirements and formulation of ration depend on monitoring the BCS (Zhang et al., 2018; Makhlouf et al., 2020). As parts of the enzymatic build-up requirements, $\mathrm{Zn}$ and $\mathrm{Se}$ are involved in different anabolic processes and cytogenetic activities which may clarify their relation with food conversion and body transformation (Ugwuja et al., 2015).

\section{CONCLUSION}

It can be concluded that the level of trace elements in breeding sheep is affected by breed, parity, age, body condition score, housing and type of feeding in central Saudi Arabia. Based on the results of the present study, it is recommended that barseem only should not be rely on as a source of trace elements for breeding ewes in arid and semiarid areas.

\section{ACKNOWLEDGEMENT}

The authors gratefully acknowledge Qassim University, represented by the Deanship of Scientific Research, on the financial support for this research under the number (Q 1-1-2019 cavm 9871) during the academic year 1440 AH / 2019 AD".

Conflict of interest: None.

\section{REFERENCES}

Abdelqader, A., Al-Yacoub, A., Gaul, M. (2012). Factors influencing productive longevity of Awassi and Najdi ewes in intensive production systems at arid regions. Small Ruminant Research. 104: 37-44.

Abuzaid, A.S., Jahin, H.S., Asaad, A.A., Fadl, M.E., AbdelRahman, M.A.E., Scopa, A. (2021). Accumulation of Potentially Toxic Metals in Egyptian Alluvial Soils, Berseem Clover (Trifolium alexandrinum L.) and Groundwater after LongTerm Wastewater Irrigation. Agriculture. 11(8): 713.

Ali, A., Derar, D.R., Alhassun, T.M., Almundarij, T.I. (2021). Effect of Zinc, Selenium and Vitamin E Administration on Semen Quality and Fertility of Male Dromedary Camels with Impotentia Generandi. Biological Trace Elements Research. 199(4): 1370-1376.

Ali, A., Derar, D.R., Alshahed, M. (2020). Management strategies, reproductive performance and causes of infertility in sheep flocks in the central region of Saudi Arabia. Tropical Animal Health and Production. 52(4): 1691-1697.
Al-Turki, T.A., Al-Namazi, A.A., Al-Ammari, B.S., Al-Mosallam, M.S., Basahi, M.A. (2020). Ex-situ conservation of wheat genetic resources from Saudi Arabia. Saudi Journal of Biological Science. 27(9): 2318-2324.

Antoniou, V., Zantopoulos, N., Tsoukali-Papadopoulou, H. (1995). Selected heavy metal concentrations in goat liver and kidney. Veterinary and Human Toxicolgy. 37(1): 20-22.

Awawdeh, M.S., Eljarah, A.H., Ababneh, M.M. (2019). Multiple injections of vitamin $E$ and selenium improved the reproductive performance of estrus-synchronized Awassi ewes. Tropical Animal Health and Production. 51(6): 1421-1426.

Dhok, A.P., Rekhate D.H. (2008). Trace elements in goats of Akola region. Indian Journal of Animal Research. 42(1): 75-76.

Ganie, A.A., Baghel, R.P.S., Mudgal, V., Aarif, O., Sheikh, G.G. (2014). Effect of Selenium supplementation on reproductive performance and hormonal profile in buffalo heifers. Indian Journal of Animal Research. 48(1): 27-30.

Grace, N.D. and Knowles, S.O. (2012). Trace element supplementation of livestock in New Zealand: Meeting the challenges of free-range grazing systems. Veterinary Medicine International. Article ID 639472. http:// dx.doi.org/10.1155/2012/639472.

Gürdoğan, F., Yildiz, A., Balikci, E. (2006). Investigation of serum $\mathrm{Cu}, \mathrm{Zn}, \mathrm{Fe}$ and Se concentrations during pregnancy $(60$, 100 and 150 days) and after parturition (45 days) in single and twin pregnant sheep. Turkish Journal of Veterinary Animal Science. 30: 61-64.

Hill, G.M., Shannon, M.C. (2019). Copper and zinc nutritional issues for agricultural animal production. Biological Trace Elements Research. 188(1): 148-159.

Hosnedlova, B., Kepinska, M., Skalickova, S., Fernandez, C., Ruttkay-Nedecky, B., Malevu, T.D., Sochor, J., Baron, M., Melcova, M., Zidkova, J., Kizek, R. (2017). A summary of new findings on the biological effects of selenium in selected animal species: A critical review. International Journal of Molecular Science. 18(10): 2209. DOI:10.3390/ijms18102209Fe.

Kumar, D.D.K., Thirumurugan, P., Sahoo, A., Naqvi, S.M.K. (2017). Ideal Housing Systems for Sheep to Cope with Climate Change. In: Sheep Production Adapting to Climate Change. [Sejian, V., Bhatta, R., Gaughan, J., Malik, P., Naqvi, S., Lal, R. (eds)]. Springer, Singapore. https:// doi.org/10.1007/978-981-10-4714-5-16.

Kumar, S., Kumar, P.A., Abdul Razzaque, W.A., Dwivedi, D.K. (2011). Importance of micro minerals in reproductive performance of livestock. Veterinary World. 4(5): 230-233. 
Factors Affecting Serum Trace Elements of Breeding Ewes in Central Saudi Arabia

Makhlouf, A., Titaouine, M., Mohamdi, H., Yakoub, F. (2020). Effect of different altitude on reproductive performances and mineral assessment in Ouled Djellal ewes during the mating period. Tropical Animal Health and Production. 52: 3275-3283.

Moffat, A.C., Jackson, J.V., Moss, M.S., Widdop, B. (1986). Metals and Anions. In: Clarke's Isolation and Identification of Drugs, [Moffat AC (ed)], $2^{\text {nd }}$ edn. The Pharmaceutical Press, London.

National Research Council (NRC) (1985). Nutrient requirements of sheep. Sixth edition. Washington, DC, USA: National Academy Press.

Nawito, M.F., Mahmoud, K.G.M., Kandiel, M.M.M., Ahmed, Y.A., Sosa, A.S.A, (2015). Effect of reproductive status on body condition score, progesterone concentration and trace minerals in sheep and goats reared in South Sinai, Egypt. African Journal of Biotechnology. 14(43): 3001-3005.

Nielsen, F.H. (2012). History of zinc in agriculture. Advances in Nutrition. 3: 783-9.

Sahlu, T., Goetsch, A.L., Luo, J., Nsahlai, I.V., Moore, J.E., Galyean, M.L., Owens, F.N., Ferrell, C.L., Johnson, Z.B. (2004). Nutrient requirements of goats: Developed equations, other considerations and future research to improve them. Small Rum Res. 53(3): 191-219.
Singh, J., Singh, V.K., Anand, M., Kumar, P., Siddiqui, M.K.J. (2010). Placental lead and its interaction with some essential metals among women from Lucknow, India. Asian Journal of Medical Science. 1: 32-36.

Stefanidou, M., Maravelias, C., Dona, A., Spiliopoulou, C. (2006). Zinc: A multipurpose trace element. Archives of Toxicology. 80: 1-9.

Ugwuja, E.I., Nnabu, R.C., Ezeonu, P.O., Uro-Chukwu, H. (2015). The effect of parity on maternal body mass index, plasma mineral element status and new-born anthropometrics. African Health Science. 15(3): 986-92.

Uslu, B.A., Mis, L., Gulyuz, F., Comba, B., Ucar, O., Tasal, I., Comba, A., Kosal, V., Sendag, S., Wehrend, A. (2017). Is there a relationship between serum minerals $(\mathrm{Ca}, \mathrm{Mg})$ and trace elements $(\mathrm{Cu}, \mathrm{Fe}, \mathrm{Mn}, \mathrm{Zn})$ at mating on pregnancy rates in fat-tailed Morkaraman sheep? Indian Journal of Animal Research. 51(2): 256-262.

Vázquez-Armijo, J.F., Rojo, R., Salem, A.Z.M., López, D., Tinoco, J.L., González, A., Pescador, N., Domínguez-Vara, I.A. (2011).Trace elements in sheep and goats reproduction: A review. Tropical and Subtropical Agro Ecosystem. 14: 1-13.

Zhang, H., Nie, H., Wang, Z., Wang, F. (2018). The net iron, manganese, copper and zinc requirements for maintenance and growth of Dorper $x$ Hu ewe lambs. Italian Journal of Animal Science. 17(4): 941-949. 